Crooked Stalks 



\section{Crooked Stalks}

Cultivating Virtue

in South India

DUKE UNIVERSITY PRESS

DURHAM AND LONDON

2009 


\section{(C) 2009}

Duke University Press

All rights reserved.

Printed in the United States of America

on acid-free paper $\infty$

Designed by Katy Clove

Typeset in Minion by

Keystone Typesetting, Inc.

Library of Congress Cataloging-in-Publication

Data appear on the last printed page of this book.

Earlier versions of parts of chapter 2 originally appeared in "Securing the Rural Citizen: The Anti-Kallar Movement of 1896,"

Indian Economic and Social History Review 42, no. 1 (2005): 1-39.

Earlier versions of parts of chapter 4 originally appeared in "Devoted to Development: Moral Progress, Ethical Work, and Divine Favor in South India," Anthropological Theory 8, no. 2 (2008): 159-79. 
To my parents

and grandparents-

for we grew in their shade,

vālai ați vālai ... 
Valiant kings of unflagging grace and ceaseless tribute remain resplendent, the scales of merchants stay in balance, the Brahmins do not forget the Vedas, and righteousness does not falter for a single day, all due to the steadily sprouting nature of the paddy fields of those who do not mistake the proper way of the world.

- ATtRibuted to The tamil poet kampar,

CA. ELEVENTH CENTURY C.E. 